\title{
Evaluation of Damage of Roundwood Assortiments Caused by Varied Construction, Technical Solutions and Conditions of Harvester Head Feed Rollers
}

\author{
Ziedonis Miklašēvičs \\ Rezekne Academy of Technologies \\ State Stock Company “Latvijas Valsts Meži” (Latvia’s State Forests) \\ Rēzekne, Latvia \\ Email: (Ziedonis Miklašēvičs): z.miklasevics@lvm.lv
}

\begin{abstract}
The purpose of this study was to evaluate the depth of damages caused by harvester head feed roller spikes to birtch veneer logs, harvested according to top diameter group $(18 \times 25 \mathrm{~cm}, 25<\mathrm{cm})$, spruce sawlogs $(6 \times 10 \mathrm{~cm})$, spruce and pine sawlogs according to top diameter group $(10 \times 14 \mathrm{~cm}, 14 \times 18 \mathrm{~cm})$.

Thirteen technical solutions and conditions of the harvester head soft feed rollers (Moipu Standard, Rib), standard feed rollers (Multi-Tree Handling (MTH), Steel Thumbnail) and agreesive feed rollers (TP) were tested in this study.

Regulation parameters of hydraulic system and angles of delimbing knife blades during the harvesting of stems in different woodland types and seasonality using single grip harvesters: John Deere 1270E, John Deere 1070E and John Deere 1070D equipped with harvester heads: H754; H480C and H460 were examined in clearcutting and thinning operations in twenty four wood felling sites in Kurzeme and Vidzeme region of Latvia.
\end{abstract}

Key words - soft feed rollers, standard feed rollers, agressive feed rollers, timber damages, roundwood assortiments

\section{INTRODUCTION}

The useful outcome of sawmaterials when sawlogs are manufactured, quality of rotary cut veneer when veneer logs are rotary peeling, wood surface quality when wood poles for power lines, building timber and posts are manufactured, depends on mechanical damages caused by harvester head feed rollers. The severity of the damage influence technical solutions and conditions of the harvester head feed rollers, regulation parameters of hydraulic system, angle of tooth of delimbing knifes, bark thickness, wood density, seasonality, professional skills of harvester operator and e.t.c. [4], [11], [1], [10], [6], [9].

According to the investigation results made by [7] the depth of damage in the tested species exhibited broad dispersion: birch 1.8-6.0, pine 4.2-8.7 and spruce 4.3$8.7 \mathrm{~mm}$, with mean values of $3.7,5.5$ and $5.8 \mathrm{~mm}$, respectively. Investigation results made by [4] revealed that the mean damage to the pine and spruce was 5.9 and $3.9 \mathrm{~mm}$, respectively. According to the investigation results made by [4] damage caused by harvester head feed rollers in the tested species wasn't deeper $10 \mathrm{~mm}$.

How the depth of damage in $10 \mathrm{~mm}$ caused by harvester head feed rollers impacts the roundwood quality? In rotary cut veneer manufacturing when the thickness of veneer is $1.26 \mathrm{~mm}$ and the birch veneer log rotary cilinder is $25 \mathrm{~cm}$, the lenght of gained veneer in peeling process is $28.9 \mathrm{~m}$. If the cilinder surface damage caused by feed rollers reaches $10 \mathrm{~mm}$, veneer in lenght $3.1 \mathrm{~m}$ (10.7\%) will be rejected because of inadequate quality. 


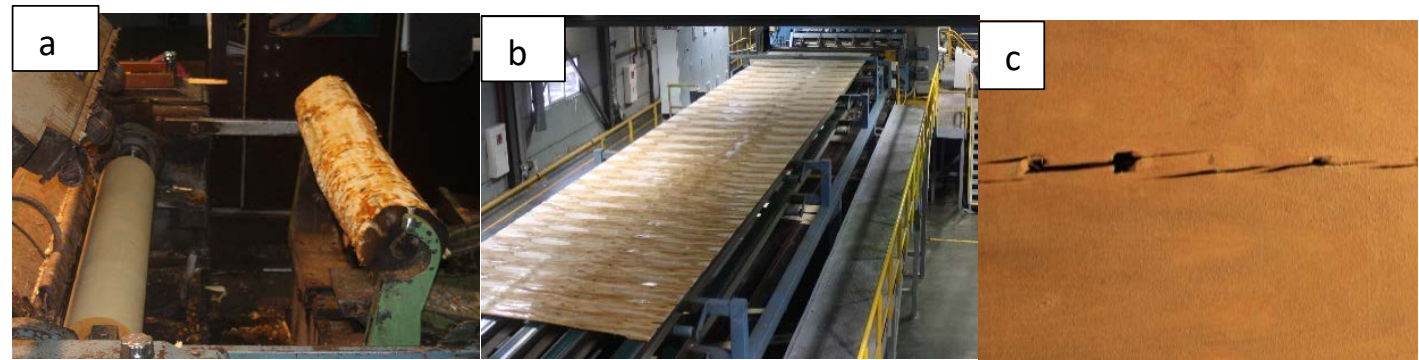

Fig.1. Cut veneer manufacturing process (a;b) and rejected veneer (c) caused by feed roller penetration in timber

In posts manufacturing process, if the roundwood (top diam. $10 \mathrm{~cm}$ ) surface damage caused by feed rollers reaches $10 \mathrm{~mm}$, a greater depth of wood requires to be removed. The technological timber loss in manufacturing process will reaches $19 \%$.

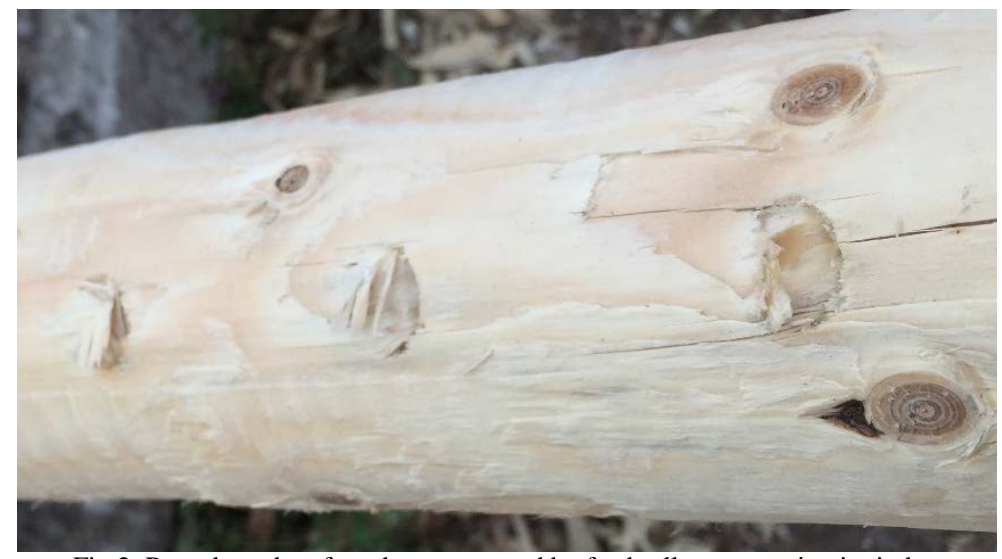

Fig.2. Roundwood surface damage caused by feed roller penetration in timber

The optimal force with which the feed rollers and delimbing knives clamp the roundwood is achieved by setting the pressing force of the hydraulic cylinders. Too low feed roller pressure comparing to delimbing knives pressure or poor technical conditons of the feed rollers and incorrect geometry of the cutting edge and sides of the knife causes bark loosening and damage on the wood surface as rollers slip. Too high pressure also causes deep roundwood damages.

Investigations in this area have been conducted in Finland, Sweden, Canada, Russia, Poland and other countries [1], [4], [6], [7], [11]. According to the investigation results made by [3], [7]. the problem related to feed roller damage has increased in Sweden and other countries, including Latvia.

\section{STUDY GOAL}

The goal of this study was to evaluate the depth of damages caused by harvester head feed roller spikes to birtch veneer logs, harvested according to top diameter group $(18 \mathrm{x} 25 \mathrm{~cm}, 25<\mathrm{cm})$, spruce sawlogs $(6 \mathrm{x} 10 \mathrm{~cm})$, spruce and pine sawlogs according to top diameter group $(10 \times 14 \mathrm{~cm}, 14 \times 18 \mathrm{~cm})$. The following objectives were set to achieve the study goal:

(i) to evaluate the technical solutions and conditions of the harvester head soft feed rollers (Moipu Standard, Rib), standard feed rollers (Multi-Tree Handling (MTH), Steel Thumbnail) and agreesive feed rollers (TP), tested in this study;

(ii) to evaluate the geometry of cutting edge and sides of the harvester upper delimbing knives;

(iii) to evaluate the harvester head feed rollers and delimbing knives pressure settings according to species and diameters of harvested assortiments;

(iv) to measure the depth of damages caused by harvester head feed roller spikes; 
(v)

to collect and analyse all measurement results

\section{MATERIALS AND METHODS}

A field study was carried out at the period Juni of 2016 - March of 2017, in Kurzeme and Vidzeme region of Latvia. Investigations were made in Myrtillosa, Vacciniosa, Hylocomniosa, Myrtillosa turf. mel., Oxalidosa, Myrtilloso-polytrichosa; Caricosophragmitosa and Aegopodiosa forwest types. In study thirteen technical solutions and conditions of the harvester head soft feed rollers (Moipu Standard, Rib), standard feed rollers (Multi-Tree Handling (MTH), Steel Thumbnail) and agreesive feed rollers (TP) were tested in clearcutting and thinning operations in twenty four wood felling sites. The technical information of the studied harvester head feed rollers is given in Table1. The investigation of feed rollers was conducted with John Deere 1270E, John Deere 1070E and John Deere 1070D equipped with harvester heads: H754; H480C and H460. In order to gather information about the depth of damages caused by harvester head feed roller spikes to birtch veneer logs, harvested according to top diameter group $(18 \times 25 \mathrm{~cm}, 25<\mathrm{cm})$, spruce sawlogs $(6 \times 10 \mathrm{~cm})$, spruce and pine sawlogs according to top diameter group $(10 \times 14 \mathrm{~cm}, 14 \times 18 \mathrm{~cm})$, the following approach, methods and data were collected:

data characterized the technical solutions and conditions of the studied feed rollers by measuring the average lenght of spikes, mm;
- data characterized the technical conditions of upper delimbung knives by measuring sharpening angles and back bevel shape using blade gauge F681744;

- data characterized regulation adjustments of feed rollers and delimbung knives according to wood species and diametrs of harvested roundwood;

- data characterized the deepest penetration point (u.b.) in most damaged zone of objected assortiment caused by inner or outer feed rollers.

Data characterized wood damage caused by harvester head feed roller slip weren't reflected in this study to avoid incorrect conslusions. The main reasons caused feed roller slip are low level of harvester operator professional skills, incorrect adjustments of hidraulic system, proportion of high-average branches, e.t.c.

\section{RESULTS AND DISCUSSION}

Data characterized the technical solutions and conditions of the studied feed rollers is given in "Table1". According to the investigation objective, the average lenght of the spikes were measured for each of the feed roller of observed 14 equipment (Fig. 3).

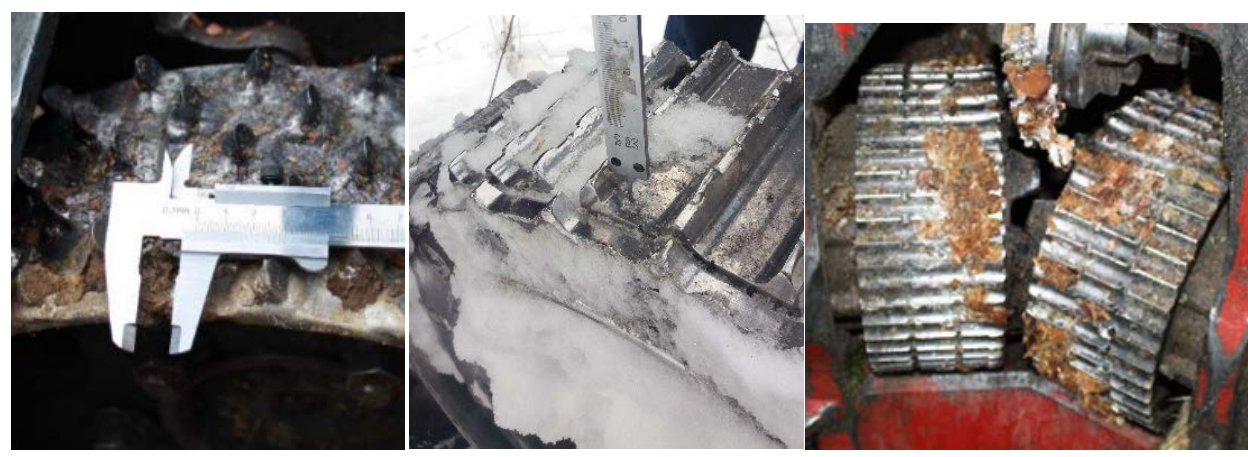

Fig.3. The lenght measurement of the feed roller spikes and evaluation the visual quality 


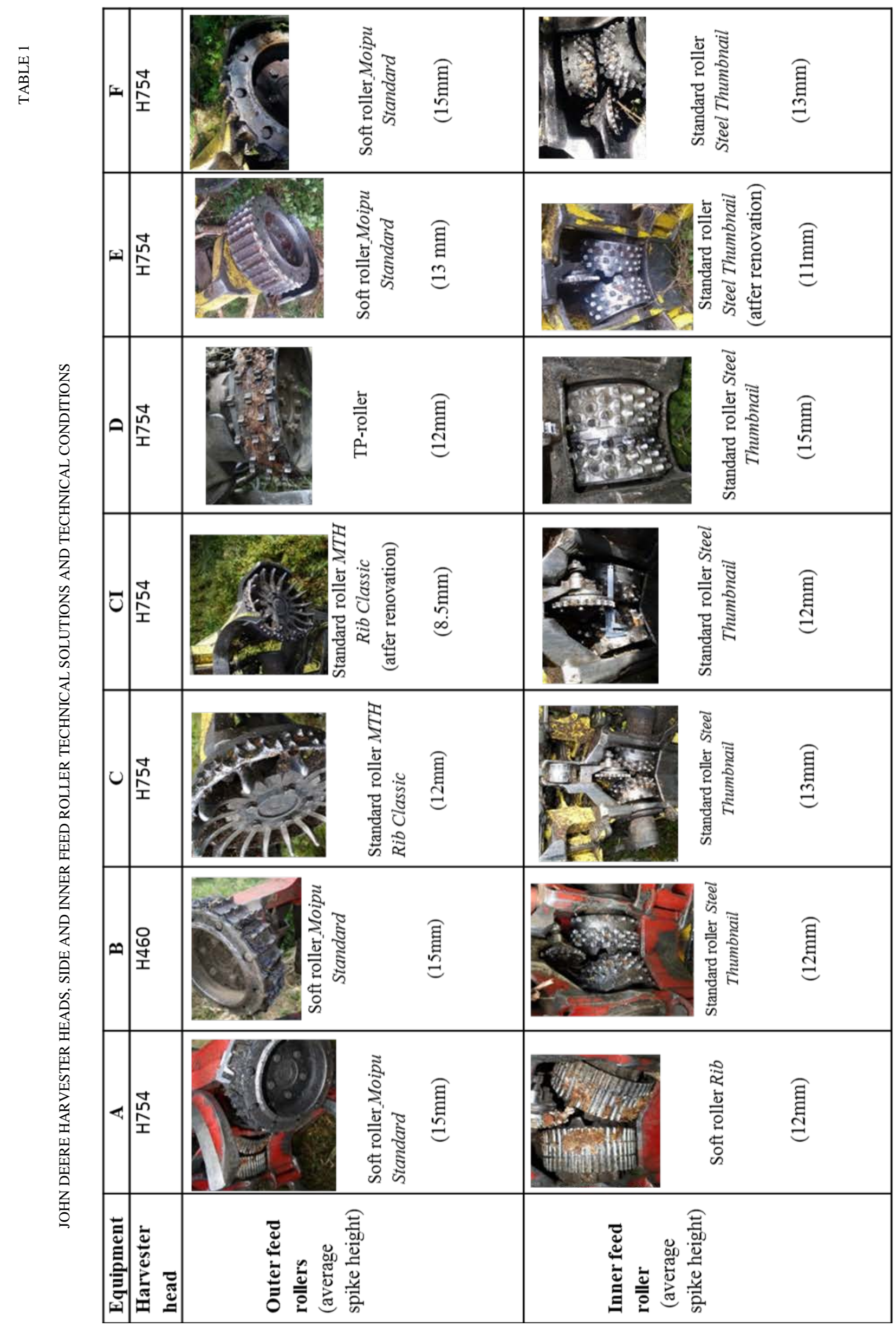


Environment. Technology. Resources. Rezekne, Latvia

Proceedings of the $13^{\text {th }}$ International Scientific and Practical Conference. Volume 3, 216-225

寊

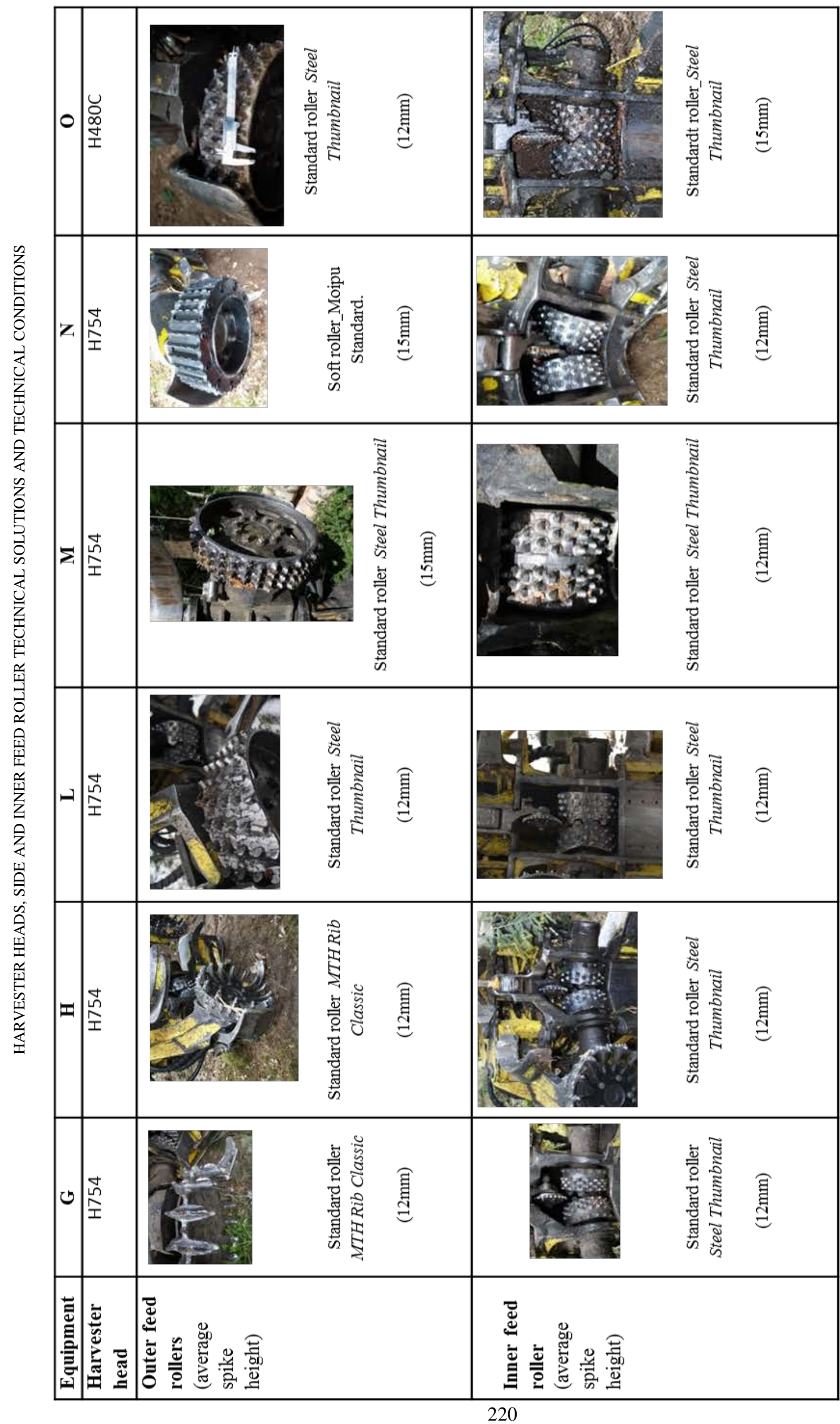


Environment. Technology. Resources. Rezekne, Latvia Proceedings of the $13^{\text {th }}$ International Scientific and Practical Conference. Volume 3, 216-225

Data characterized the deepest penetration point in most damaged place of objected assortiment caused by inner or outer feed rollers is given in Table 2 .

TABLE 2

FEED ROLLER DAMAGES OF SPRUCE, PINE AND BIRCH ROUNDWOOD ASSORTIMENTS

\begin{tabular}{|c|c|c|c|c|c|c|c|c|c|c|}
\hline & & & & Feed & ller pen & tration d & $\begin{array}{l}\text { pth (med } \\
\text { p.s. innel }\end{array}$ & $\begin{array}{l}\text { (average) } \\
\text { ller }\end{array}$ & timber & ., mm) \\
\hline & & & & Spru & $\begin{array}{l}\text { roundwc } \\
\text { ameter, c }\end{array}$ & d (top & $\begin{array}{r}\text { Pine ro } \\
\text { dian }\end{array}$ & $\begin{array}{l}\text { wood (top } \\
\text { r, cm) }\end{array}$ & $\begin{array}{l}\text { Birch } \mathrm{r} \\
\text { (top dia }\end{array}$ & $\begin{array}{l}\text { hdwood } \\
\text { ter, cm) }\end{array}$ \\
\hline 节 & 崩范 & 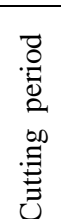 & 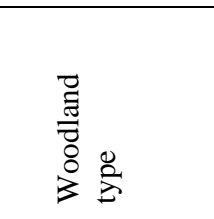 & $6 \times 10$ & $12 \times 14$ & $14 \times 18$ & $12 \times 14$ & $14 \times 18$ & $20 \times 30$ & $30>$ \\
\hline $\mathrm{A}$ & $\begin{array}{l}\text { Clear } \\
\text { cutting }\end{array}$ & 09 & Myrtillosa & & $\frac{2.2 / 3.0}{5.7 / 5.4}$ & & & $\frac{1.9 / 1.9}{4.7 / 4.8}$ & & \\
\hline B & $\begin{array}{l}\text { Thin- } \\
\text { ning }\end{array}$ & 07 & Vacciniosa & $\frac{2.5 / 3.2}{2.8 / 3.2}$ & $3.6 / 3.8$ & $2.9 / 3.1$ & $\underline{3.0 / 2.5}$ & $\frac{2.8 / 2.2}{3.6 / 3.4}$ & $\frac{1.8 / 1.5}{2.7 / 3.2}$ & $\frac{1.3 / 1.2}{3.4 / 3.4}$ \\
\hline $\mathrm{C}$ & $\begin{array}{l}\text { Thin- } \\
\text { ning }\end{array}$ & 09 & Vacciniosa & & $\frac{5.8 / 5.9}{3.8 / 3.4}$ & & & $\frac{5.4 / 5.4}{3.7 / 3.8}$ & & \\
\hline $\mathrm{C} 1$ & $\begin{array}{l}\text { Thin- } \\
\text { ning }\end{array}$ & 09 & Vacciniosa & & & $\underline{3.5 / 3.8}$ & $\underline{5.5 / 5.4}$ & $\underline{5.9 / 6.0}$ & & \\
\hline $\mathrm{D}$ & $\begin{array}{l}\text { Clear } \\
\text { cutting }\end{array}$ & 06 & Hylocom-niosa & $1.8 / 2.2$ & $2.4 / 2.4$ & & $2.4 / 2.2$ & $\frac{3.6 / 3.8}{4.4 / 4.3}$ & $\underline{2.4 / 2.6}$ & \\
\hline $\mathrm{E}$ & $\begin{array}{l}\text { Clear } \\
\text { cutting }\end{array}$ & $\begin{array}{l}07 \\
08\end{array}$ & $\begin{array}{l}\text { Hylocom-niosa } \\
\text { Myrtillosa turf. } \\
\text { mel. }\end{array}$ & 3.3/3.2 & $\begin{array}{l}3.5 / 3.3 \\
3.8 / 3.7\end{array}$ & $\begin{array}{l}5.5 / 5.4 \\
6.3 / 6.4\end{array}$ & $\begin{array}{l}3.4 / 3.6 \\
3.4 / 3.6\end{array}$ & $\begin{array}{l}3.5 / 3.4 \\
3.5 / 3.4\end{array}$ & $\begin{array}{l}\frac{2.0 / 2.1}{1.3 / 1.1} \\
\frac{3.0 / 3.2}{3.4 / 3.5}\end{array}$ & \\
\hline $\mathrm{F}$ & $\begin{array}{l}\text { Thin- } \\
\text { ning }\end{array}$ & 07 & Oxalidosa & $\frac{2.5 / 2.5}{2.5 / 2.3}$ & & 3.9/3.0 & $\underline{3.0 / 3.2}$ & $\frac{3.6 / 3.8}{1.8 / 1.7}$ & $\frac{1.7 / 1.8}{3.5 / 3.6}$ & \\
\hline & $\begin{array}{l}\text { Clear } \\
\text { cutting }\end{array}$ & $\begin{array}{l}12 \\
02 \\
03\end{array}$ & $\begin{array}{l}\text { Oxalidosa } \\
\text { Oxalidosa } \\
\text { Hylocomniosa }\end{array}$ & & & $\begin{array}{c}3.6 / .3 . \\
3\end{array}$ & $\begin{array}{l}5.1 / \\
4.9\end{array}$ & $\begin{array}{l}7.2 / 7.6 \\
3.1 / 3.4\end{array}$ & $\begin{array}{l}3.8 / 3.8 \\
4.8 / 5.2\end{array}$ & $3.5 / 3.4$ \\
\hline G & $\begin{array}{l}\text { Thin- } \\
\text { ning }\end{array}$ & $\begin{array}{l}07 \\
11\end{array}$ & $\begin{array}{l}\text { Oxalidosa; } \\
\text { Myrtilloso- } \\
\text { polytrichosa; } \\
\text { Caricoso- } \\
\text { phragmitosa }\end{array}$ & $\frac{5.2 / 5.2}{4.5 / 4.2}$ & 3.8/3.6 & $\begin{array}{l}\frac{6.5 / 6.6}{3.5 / 3.8} \\
3.9 / 3.9\end{array}$ & & $3.7 / 3.6$ & & \\
\hline $\mathrm{H}$ & $\begin{array}{l}\text { Thin- } \\
\text { ning }\end{array}$ & 08 & $\begin{array}{l}\text { Hylocomniosa; } \\
\text { Myrtillosa mel.; } \\
\text { Oxalidosa }\end{array}$ & & & $\frac{4.5 / 4.6}{2.4 / 2.4}$ & & $3.7 / 3.6$ & $\begin{array}{l}\frac{4.2 / 4.1}{3.4 / 3.7} \\
\end{array}$ & \\
\hline $\mathrm{L}$ & $\begin{array}{l}\text { Clear } \\
\text { cutting }\end{array}$ & 11 & Hylocomniosa & & $2.0 / 2.3$ & $2.2 / 2.3$ & & $3.7 / 3.6$ & $3.3 / 3.3$ & $3.1 / 3.2$ \\
\hline $\mathrm{M}$ & $\begin{array}{l}\text { Clear } \\
\text { cutting }\end{array}$ & 08 & Hylocomniosa & $0.5 / 0.6$ & $1.2 / 1.3$ & $2.7 / 3.6$ & & & $2.5 / 2.7$ & $2.5 / 2.6$ \\
\hline $\mathrm{N}$ & $\begin{array}{l}\text { Clear } \\
\text { cutting }\end{array}$ & 10 & Oxalidosa & $3.4 / 3.7$ & $3.6 / 3.8$ & $3.5 / 3.8$ & & $3.1 / 3.1$ & $2.9 / 3.2$ & $3.3 / 3.8$ \\
\hline $\mathrm{O}$ & $\begin{array}{l}\text { Clear } \\
\text { cutting }\end{array}$ & 08 & Aegopodiosa & & $3.5 / 4.2$ & & & & & \\
\hline
\end{tabular}


Environment. Technology. Resources. Rezekne, Latvia Proceedings of the $13^{\text {th }}$ International Scientific and Practical Conference. Volume 3, 216-225

The deepest penetration point in most damaged zone of objected assortiment caused by inner or outer feed rollers was measured under bark (u.b.) by using penetration calliper (Fig. 2). The measurement zone was chosen in $50 \mathrm{~cm}$ lenght. The measurements were taken in sampling plots which average area was about $60 \mathrm{~m}^{2}$. According to the investigation task the penetration depth caused by feed rollers were observed and measured in each of objective assortiments (Fig. 4).
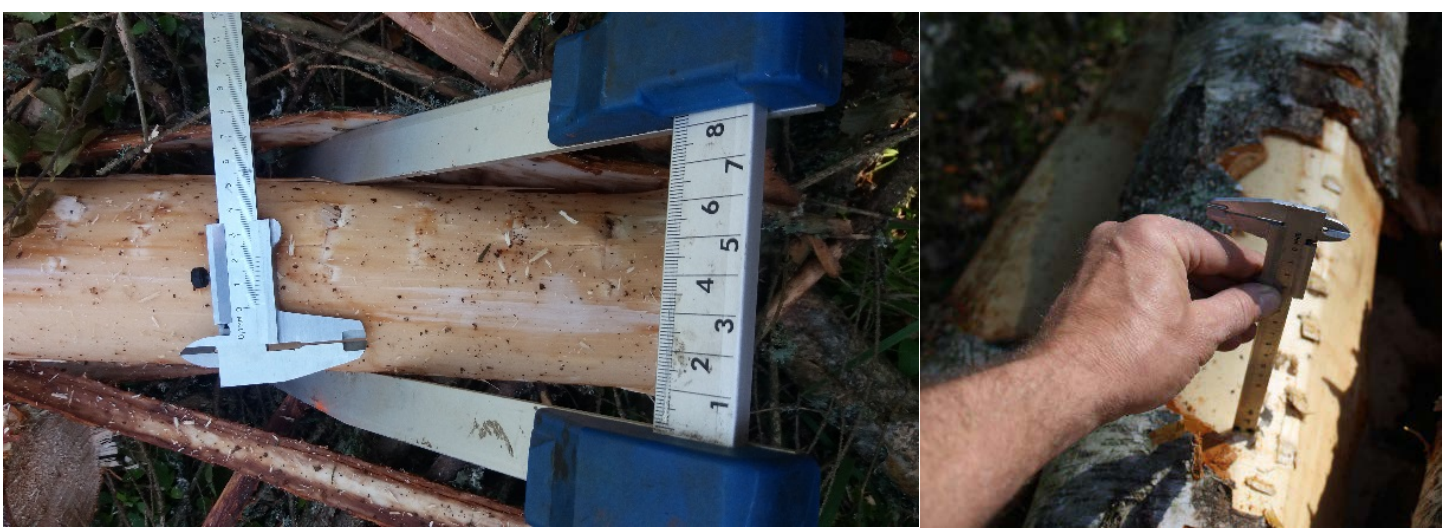

Fig. 4. The measurement of feed roller damage depth in timber

The technical conditions and back bevel shape of upper delimbung knives were evaluated by measuring angles of cutting edge and surface flatness using blade gauge F681744 (Fig. 5).

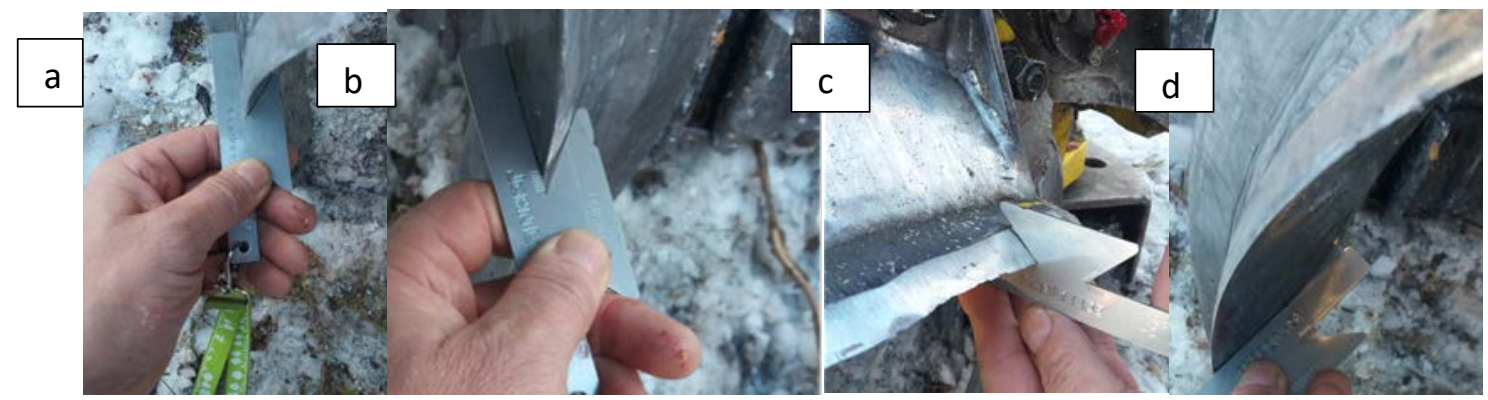

Fig. 5. The measurement of angle of cutting edge and surface flatness of top and upper delimbing knives (d) using blade gauge F681744, where (a; c) - correctly sharpened knife (36deg.); (b)- uncorrectly sharpened knife(>36 deg.)

Observation results of delimbing knives and fixed top knife is given in Fig. 6.

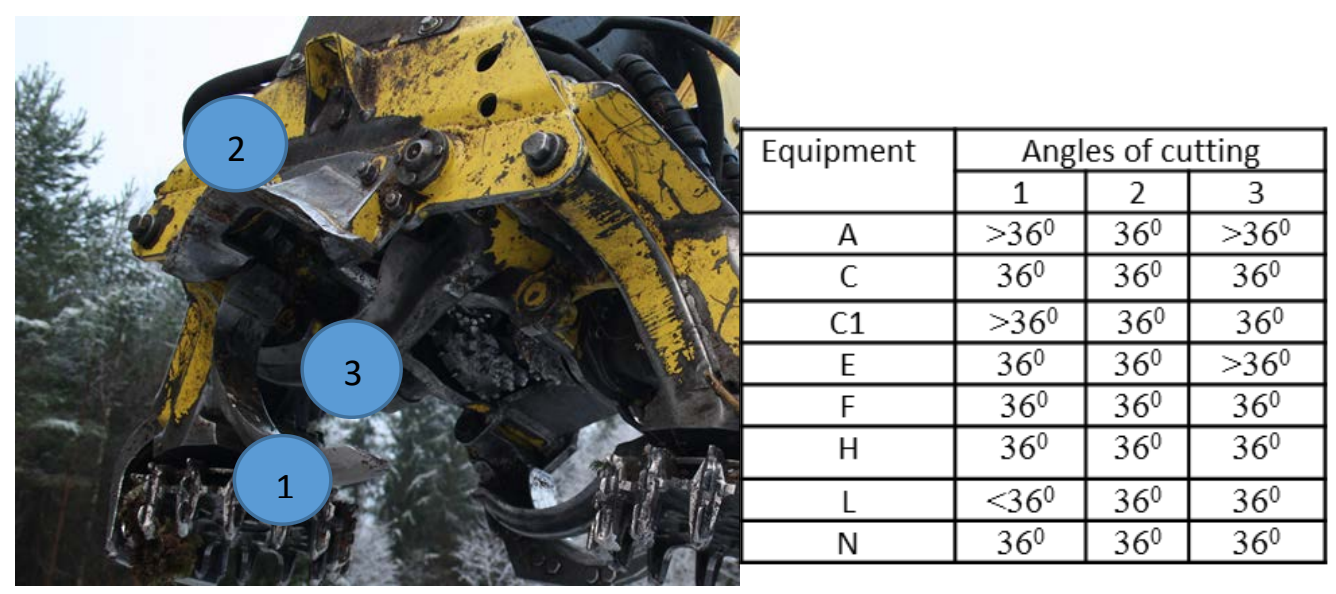

Fig. 6. The points of measurement and observation results, where 1 - right upper delimbing knife; 2- top knife; 3 - left upper delimbing knife 
Environment. Technology. Resources. Rezekne, Latvia Proceedings of the $13^{\text {th }}$ International Scientific and Practical Conference. Volume 3, 216-225

Data characterized regulation adjustments of feed rollers and delimbung knives according to wood species and diametrs of harvested roundwood is given in Table 3 .

TABLE 3

REGULATION ADJUSTMENTS OF FEED ROLLERS AND DELIMBING KNIVES OF EQUIPMENTS A;C;C1;E;F;H;L;N ACCORDING TO WOOD SPECIES AND DIAMETERS OF HARVESTED ROUNDWOOD

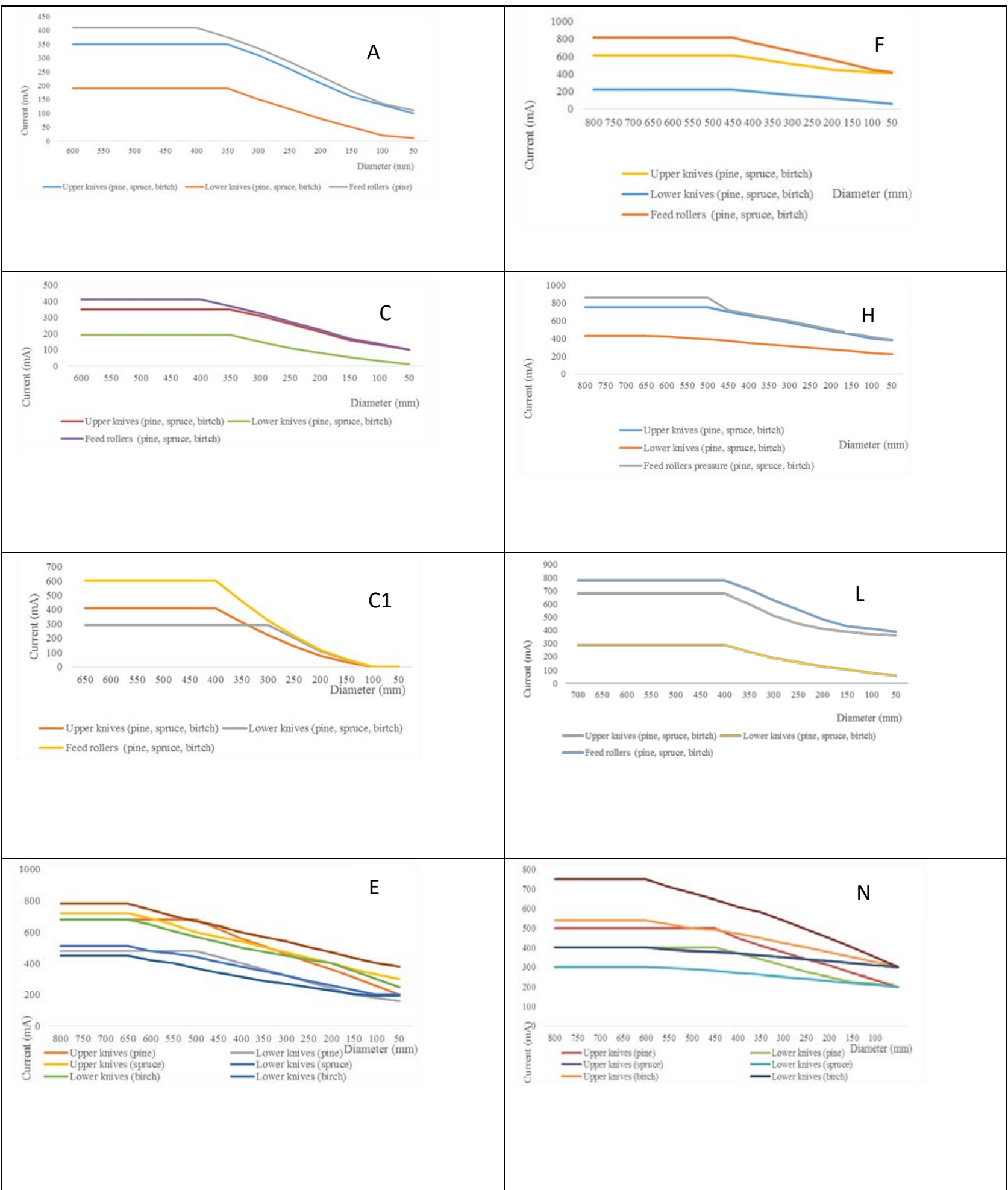




\section{CONCLUSIONS AND RECOMENDATIONS}

The results of the study indicated the following:

1. The incorrect maintenance of the fixed knife and upper delimbing knives when the actual angle of cutting exceed the recommended $36^{0}$ causes cutting them into the stem. Therefore, the penetration depth in timber caused of spikes of harvester head feed rollers increases. The main reasons when the actual angle of cutting differs from the recommended are:

1.1.the surface deterioration of upper delimbing knifes exceeds the recommended $(>2 \mathrm{~mm})$;

1.2.the width of delimbing knife reaches the critical, when the correct maintenance is impossible due to designed parameters of the knife;

1.3.ignorance of recommended angle of cutting in the process of sharpening

2. If the lenght of the feed roller spikes of inner feer roller are longer comparing to the outer feed rollers, the deepest penetration in timber made the inner feed roller.

3. In cases when inner feed roller is aggressive or standard but outer feed rollers respectively standard or soft, the deepest penetration in timber made inner feed roller.

4. The deepest feed roller damages (median) caused by:

4.1. inner feed roller were observed in spruce roundwood $(14 \times 18 \mathrm{~cm})$ when the penetration depth in timber reached $6.5 \mathrm{~mm}$;

4.2. outer feed rollers were obseved in pine roundwood $(14 \times 18 \mathrm{~cm})$ when the penetration depth in timber reached $7.2 \mathrm{~mm}$

5. The deepest feed roller damages (median) of spruce roundwood $(6 \times 10 \mathrm{~cm})$ made inner roller $5.2 \mathrm{~mm}$.

\section{VI . REFERENCES}

[1] Y. Gerasimov, A. Seliverstov, and V. Syunev, Industrial round-wood damage and operational efficiency losses associated with the maintenance of a single-grip harvester head model: A case study in Russia. Forests 3: 2012, pp. 864-880.

[2] John Deere. Operation and Maintenance Manual for Harvester Head John Deere 758HD; John Deere: Moline, IL, USA, 2008.

[3] P .Jönsson and B. Hannrup, 2007. Virkesvärdestest 2006 - virkesskador [Timber-value tests 2006 - timber damage and defects]. Skogsforsk Resultat 2007 (7). 4 p.

[4] Z. Karasewski and A. Lacka, "Damage caused by harvester head feed rollers to alder, pine and spruce". Drewno 2016, Vol. 59.

[5] A. Kariniemi, Kuljettajakeskeinen hakkuukonetyönmalli - työn suorituksen kognitiivinen tarkastelu [Operator-specific model for mechanical
6. The deepest feed roller damages (median) of spruce roundwood $(12 \times 14 \mathrm{~cm})$ made inner roller $5.8 \mathrm{~mm}$.

7 The deepest feed roller damages (median) of pine roundwood $(12 \times 14 \mathrm{~cm})$ made inner roller $5.5 \mathrm{~mm}$.

8. The deepest feed roller damages (median) of birch roundwood $(20 \times 30 \mathrm{~cm})$ made outer rollers $4.8 \mathrm{~mm}$.

9. The deepest feed roller damages (median) of birch roundwood $(30<\mathrm{cm})$ made outer rollers $3.5 \mathrm{~mm}$.

10. To reduce the depth of penetration in timber caused by feed rollers, the following recomendations are given:

5.1.to inspect regulary feed roller spikes technical conditions, angles of cutting and tehnical conditions of delimbing knifes;

5.2.to maintain optimal pressure settings of feed rollers and delimbing knifes according to wood species and harvested roundwood diameters;

5.3.the pressure of feed rollers should be at least 20 bar. higher comparing to upper delimbing knifes;

5.4.to set up the harvester head with the same tape and conditions inner and outer feed rollers when (Multi-Tree Handling (MTH), Steel Thumbnail) and agreesive feed rollers (TP) are used;

5.5.in cases when soft feed rollers (Moipu Standard,Rib) are used as outer feed rollers, the inner should be standard feed rollers with the same lenght parametrs of spikes.

5.6. to avoid using soft feed rollers as inner rollers due to clotting them with bark what caused slippage and deep timber damades. harvesting - cognitive approach to work performance].Helsingin yliopiston metsävarojen käytön laitoksen julkaisuja 38, 2006, 126 p.

[6] P. S. Mederski, Możliwości zastosowania harwestera do pozyskiwania drewna w mieszanych drzewostanach brzozowo-sosnowych (The potential of harvester use for thinning operations in mixed birch-pine stands). Wydawnictwo Uniwersytetu Przyrodniczego w Poznaniu, Poznań 2013.

[7] Y.Nuutinen and K.Väätäinen, "Operational efficiency and damage to sawlogs by feed rollers of the harvester head”. Silva Fenn., 44, 2010, pp. 121-139.

[8] H. Ovaskainen, “Timber harvester operators'working technique in first thinning and the importance of cognitive abilities on work productivity". Dissertationes Forestales 79, 2009, 62p.

[9] R. Spinelli and N. Magagnoti , "Work quality and veneer value recovery of mechanized and manual logmaking in Italian poplar plantations". European Journal of Forest Research 130, 2011, pp.737-744. 
Environment. Technology. Resources. Rezekne, Latvia Proceedings of the $13^{\text {th }}$ International Scientific and Practical Conference. Volume 3, 216-225

[10] K.Väätäinen and H. Ovaskainen, Hakkuukoneenkuljettajan hiljaisen tiedon merkitys hakkuutulokseen työpistetasolla (The significance of harvester operator's tacit knowledge on cutting with single grip harvester). Metsäntutkimuslaitoksen tiedonantoja 937, 2005, $100 \mathrm{p}$.
[11] A. Węgrzyn and N. Leszczyński N, "Rolki posuwu głowic harwesterowych (Feed rollers in harvester heads).” Technika Ogrodnicza Rolnicza i Leśna 3. 2014, pp. 6-8. 